\title{
REFLEXO DO REGIME DE BENS NO DIREITO CONCORRENCIAL SUCESSÓRIO
}

\author{
André Luis Rodrigues Pedrozo ${ }^{1}$
}

\section{INTRODUÇÃO}

O Código Civil de 2002 dividiu a tutela jurídica da família em dois títulos. No primeiro, tratou do direito pessoal de família, baseado na afetividade do enlaço matrimonial necessária para o livre desenvolvimento da personalidade. Já no segundo, tratou do direito patrimonial de família, o qual não é envolto no afeto, mas sim em disposições sobre os bens amealhados no interregno do casamento.

O jurista Clóvis do Couto Silva, responsável pela Relatoria das propostas de modificação no Direito de Família, apresentou inovação sistemática à estrutura do Livro. Preocu- pado com as relações emergentes dos vínculos familiares, optou por dividi-las de acordo com a carga de personalidade que fossem dotadas. ${ }^{2}$

$\mathrm{O}$ que nos interessa no presente ensaio, e como o título sugere, é o reflexo do direito patrimonial quando do decesso de um dos cônjuges, reverberando no direito concorrencial sucessório a depender de qual regime de bens foi adotado.

A proposta primeva deste artigo é apresentar uma visão geral dos regimes de bens tipificados no ordenamento jurídico, apresentando-os como ponto principal na concorrência sucessória do cônjuge com os descendentes do de cujus.

1 Advogado militante, especializando em Direito Civil e Processo Civil, aluno ouvinte da Turma de Mestrado em Direito de Família e Sucessões na Universidade Federal do Rio Grande do Sul (UFRGS).

2 COStalungA. Karime. Direito de Herança e Separação de Bens. São Paulo: Quartier Latin, 2009, p. 25. 
Desta forma, prefacialmente, abordaremos os regimes de bens esposados no Código Civil. Ao depois, será analisada a concorrência sucessória, exclusivamente dos descendentes. Por fim, analisaremos a participação do cônjuge na herança nos regimes de bens com maior polêmica, quais sejam: comunhão parcial e separação de bens, às quais será dada ênfase à jurisprudência do Tribunal gaúcho e também do Superior Tribunal de Justiça.

\section{DOS REGIMES DE BENS}

Os regimes de bens constituem os princípios que disciplinam as relações econômicas entre os cônjuges na constância do matrimônio. ${ }^{3}$ Podemos, também, conceituar como as relações econômicas que disciplinam e regem o patrimônio trazido ou adquirido pelo casal durante o casamento, regidos por uma legislação específica, até sua extinção.

\subsection{Histórico}

Sua origem, ainda primitiva, foi nos primórdios do direito romano.
A família no direito pré-clássico caracterizava-se pela rigidez patriarcal, pois "os poderes do pater famílias sobre as pessoas a ele submetidas se designam, a princípio, com uma única palavra: manus". "Todo patrimônio da família lhe pertence; daí tudo que as pessoas, que lhe são submetidas, adquirem passa a pertencer a ele". 4

Ao casar, a mulher sujeitava-se "à autoridade (manus) do marido. A $M a-$ $n u s$, ou seja, esse ato de dominação, se estabelecia por meio de três diferentes procedimentos: usus, confarreatio ou coemptio. O Usus consistia simplesmente na submissão contínua da mulher ao homem, durante um ano, representando uma entrega de fato. Esse período, sendo ininterrupto, permitia a consolidação da manus, dando-lhe contornos jurídicos: espécie de casamento por usucapião. A confarreatio era uma cerimônia, semelhante ao casamento de hoje, realizada na presença de testemunhas e sob a presidência do grande pontífice. Como em qualquer solenidade, em qualquer religião, deus nenhum dispensa oferendas, nesse ato solene se oferecia um pastel de farinha (farreum) a Júpiter. A coemptio, como a própria palavra indica, não

3 PEREIRA, Caio Mário da Silva. Instituições ao direito civil. Direito de Família. V. V, 18. ed. Rio de Janeiro: Editora Forense, 2010, p. 189.

4 ALVES, José Carlos Moreira. Direito Romano. V. II, 6. ed. Rio de Janeiro: Editora Forense, 2001, p. 249.

5 CARVALHO. João Andrades. Regime de bens. Rio de Janeiro: Editora Aide, 1996, p. 11-12. 
representa senão uma venda ficta da mulher ao varão". 5

Os bens da mulher que se sujeitava ao marido (manus) eram a ele transferidos em sua totalidade.

Importante citar os ensinamentos de Rudolph Von Ihering ${ }^{6}$ :

En el estado antiguo, que descansa sobre el principio de familia, el matrimonio tuvo un grave carácter particular. Acto religioso, su disolucion no era posible sino en muy pequeño número de casos, y sólo con la intervencion de los sacerdotes. ${ }^{?}$

Ocorre que, com a evolução da sociedade romana e o número de divórcios aumentando, as mulheres, não raras vezes, com a morte do esposo, ficavam desnudadas de qualquer patrimônio para a mantença do mínimo existencial, uma vez que todos seus aprestos passavam para o marido.

Diante desta situação periclitante, surgiu uma ação especial denominada rei uxoriae, conhecida também como actio injusti repundii, na qual a mulher tentava, pelo menos, a devolução de parte de seus bens que foram entregues ao marido. ${ }^{8}$

Com o avanço da história, os povos de forte influência romanista, como o Brasil, assimilaram em seus ordenamentos a concepção romana.

\subsection{No Brasil}

Quando da edição do Código Civil de 1916, a família era exclusivamente constituída pelo matrimônio. $\mathrm{O}$ casamento era indissolúvel, levandose a uma união plena de vida e de patrimônio. O regime legal era o da comunhão universal de bens. ${ }^{9}$

Com a edição da Lei 4.121/62 (Estatuto da Mulher Casada), por meio da qual foram alterados alguns dispositivos do Código Civil vigente à época, iniciou-se timidamente a modificação do caráter de igualdade da mulher na sociedade conjugal.

Houve uma verdadeira evolução com a Lei do Divórcio (Lei 6.515/77), passando o regime leal de bens "a ser o da comunhão parcial, que afasta a comunicação do acervo adquirido

6 IHERING, Rudolph Von. El espíritu del Derecho Romano em las diversas fases de su desarrolho.Tomo I. Granada: Editora Comares, 1998, p. 154.

7 Tradução Livre: "No estado antigo, que se baseia no princípio de família, o casamento teve um caráter particular sério. Como tratava-se de ato religioso, a sua dissolução só era possível em alguns poucos casos, e apenas com a intervenção dos sacerdotes".

8 CARVALHO. Op. cit., p. 12.

9 DIAS, Maria Berenice. Manual de Direito das Famílias, 9. ed. São Paulo: Editora Revista dos Tribunais, 2013, p. 226. 
antes do casamento. As heranças, os legados e as doações percebidos por um dos cônjuges, a qualquer tempo, antes ou durante a vigência do matrimônio, igualmente não se comunicam. O estado de condomínio se estabelece somente com relação aos aquestos, isto é, os bens adquiridos no período da vida em comum, com escassas exceções". ${ }^{10}$

A igualdade plena de direitos entre homens e mulheres atingiu seu ápice com a promulgação da Constituição Federal de 1988. Dita isonomia, por óbvio, refletiu no regime de bens, principalmente quanto à administração do patrimônio do casal.

O Código Civil de 2002 propôs aos nubentes quatro regimes de bens: comunhão universal, comunhão parcial, separação e participação final dos aquestos.

Estes são os regimes que livremente podem escolher os cônjuges. Contudo, havendo alguma das causas do art. 1641 do Código Civil, a lei impõe de forma cogente a separação obrigatória de bens.
Inicialmente, iremos abordar de forma breve alguns aspectos dos regimes de bens esposados no Código Civil e, ao final, daremos relevância maior para os regimes de comunhão parcial e separação de bens.

Como dito alhures, os cônjuges podem escolher livremente o regime de bens que melhor lhes aprouver, desde que não hajam os impedimentos já referidos. É facultando, inclusive, criar regimes híbridos por meio da confecção de pacto antenupcial, exigindo-se apenas que não contenha convenção ou cláusula que contravenha disposição absoluta de lei.

\subsection{Da Comunhão Parcial de Bens}

No regime de comunhão parcial de bens (art. 1658 do Código Civil ${ }^{11}$ ), que, diga-se de passagem, não havendo convenção das partes exteriorizada pelo pacto antenupcial, (arts. 1640 e $1653^{12}$, ambos, do Código Civil), é o regime legal vigente, comunicam-se os bens adquiridos a título oneroso

10 DIAS, Família. Op. cit., p. 227.

11 Art. 1.658. No regime de comunhão parcial, comunicam-se os bens que sobrevierem ao casal, na constância do casamento, com as exceções dos artigos seguintes.

12 Art. 1.640. Não havendo convenção, ou sendo ela nula ou ineficaz, vigorará, quanto aos bens entre os cônjuges, o regime da comunhão parcial. Art. 1.653. É nulo o pacto antenupcial se não for feito por escritura pública, e ineficaz se não lhe seguir o casamento. 
na constância do casamento, exceto os previstos no art. 1659 do Código Civil $^{13}$.

Silvio de Salvo Venosa aduz:

A ideia central no regime da comunhão parcial, ou comunhão de adquiridos, como é conhecido no direito português, é a de que os bens adquiridos após o casamento, os aquestos, formam a comunhão de bens do casal. Cada esposo guarda para si, em seu próprio patrimônio, os bens trazidos antes do casamento. É o regime legal, o que vigora nos casamentos sem pacto antenupicial ou cujos pactos sejam nulos $[\ldots]^{14}$

\section{Paulo Lôbo complementa:}

O que singulariza o regime, considerado por muitos o mais equitativo, é a separação e convivência entre dois tipos de bens: os comunicáveis, ou comuns, e os não comunicáveis, ou particulares. Resultam três massas patrimoniais distintas, cada uma com seus respectivos ativos e passivos: duas particulares e uma comum. ${ }^{15}$

\subsection{Da Comunhão Universal}

Até a entrada em vigor da Lei do Divórcio (Lei 6.515/77), era o regime de bens vigente, quando os nubentes não firmavam escritura pública diversa.

Consoante art. 1667 do Código Civil ${ }^{16}$, na espécie comunicam-se todos os bens, quer sejam adquiridos antes ou após o casamento, salvo poucas exceções, elencadas no art. $1.668^{17}$ do Código Civil.

13 Art. 1.659. Excluem-se da comunhão: I. os bens que cada cônjuge possuir ao casar, e os que lhe sobrevierem, na constância do casamento, por doação ou sucessão, e os sub-rogados em seu lugar; II. os bens adquiridos com valores exclusivamente pertencentes a um dos cônjuges em sub-rogação dos bens particulares; III. as obrigações anteriores ao casamento; IV. as obrigações provenientes de atos ilícitos, salvo reversão em proveito do casal; V. os bens de uso pessoal, os livros e instrumentos de profissão; VI. os proventos do trabalho pessoal de cada cônjuge; VII. as pensões, os meios-soldos, os montepios e outras rendas semelhantes.

14 VENOSA, Silvio Salvo. Direito Civil: Direito de família. 5. ed. São Paulo: Editora Atlas, 2005, p. 365.

15 LÔBO. Paulo. Direito Civil. Famílias. 2. ed. São Paulo: Editora Saraiva, 2009, p. 317.

16 Art. 1.667. O regime de comunhão universal importa a comunicação de todos os bens presentes e futuros dos cônjuges e suas dívidas passivas, com as exceções do artigo seguinte.

17 Art. 1.668. São excluídos da comunhão: I. os bens doados ou herdados com a cláusula de incomunicabilidade e os sub-rogados em seu lugar; II. os bens gravados de fideicomisso e o direito do herdeiro fideicomissário, antes de realizada a condição sus- 
No escólio de Caio Mario, que aduz:

O que caracteriza o regime de comunhão universal é a comunicação de todos os valores, móveis ou imóveis, de que cada um dos cônjuges é titular ao tempo das núpcias, e bem assim os que forem adquiridos na constância do matrimônio, posto que adquiridos por um deles apenas. Comunicam-se igualmente as dívidas, anteriores e posteriores. Além de outras exceções, legais ou convencionais, eventualmente estabelecidas, o artigo seguinte exclui da comunhão os bens ou dívidas que menciona. ${ }^{18}$

\subsection{Da Separação De Bens}

No regime de separação de bens, o legislador substantivo evidenciou que cada consorte administra-se seus bens como melhor lhe aprouve-se (art. 1687 do Código Civil $\left.{ }^{19}\right)$. Inclusive, achou-se por bem, expressamente expungir a norma esculpida no art. 1647, inciso I, do Código Civil ${ }^{20}$.

No regime de separação de bens, "cada cônjuge conserva a plena propriedade, a integral administração e a fruição de seus próprios bens, podendo aliená-los e gravá-los de ônus real livremente, sejam móveis ou imóveis." 21

No regime de separação de bens, cumpre dizer que há duas espécies, quais sejam: a) separação obrigatória de bens, esculpida no art. 1641 do Código Civil22, e b) a separação convencional/livre/espontânea de bens, regrada pelo pacto antenupcial.

No referido regime de bens, sequer tem o cônjuge sobrevivente direito de meação dos bens. Por óbvio, esta regra deve ser relativizada face ao teor da Súmula n 377 do Supremo Tribunal Federal ${ }^{23}$. Embora o enun-

pensiva; III. as dívidas anteriores ao casamento, salvo se provierem de despesas com seus aprestos, ou reverterem em proveito comum; IV. as doações antenupciais feitas por um dos cônjuges ao outro com a cláusula de incomunicabilidade; V. os bens referidos nos incisos V a VII do art. 1.659.

18 PEREIRA, Op. cit., p. 230.

19 Art. 1.687. Estipulada a separação de bens, estes permanecerão sob a administração exclusiva de cada um dos cônjuges, que os poderá livremente alienar ou gravar de ônus real.

20 Art. 1.647. Ressalvado o disposto no art. 1.648, nenhum dos cônjuges pode, sem autorização do outro, exceto no regime da separação absoluta: I. alienar ou gravar de ônus real os bens imóveis.

21 GONÇALVES. Carlos Roberto. Direito Civil brasileiro. V. 6: Direito de família. 8. ed. São Paulo: Editora Saraiva, 2011, p. 490.

22 Art. 1.641. É obrigatório o regime da separação de bens no casamento.

23 Súmula 377: No regime de separação legal de bens comunicam-se os adquiridos na constância do casamento. 
ciado refira-se a separação legal, o mesmo deve ser interpretado em harmonia principiológica com os ditames constitucionais da igualdade ${ }^{24}$ e dignidade da pessoa humana ${ }^{25}$.

Importa saber se no regime de separação de bens (legal ou convencional) o cônjuge supérstite tem direito sucessório concorrente.

\subsection{Da participação final nos aquestos}

A fim de não passar incólume, o regime de participação final dos aquestos, que não vingou no Brasil, segue as regras do art. 1672 do Código Civil ${ }^{26}$.

\section{DO DIREITO SUCESSÓRIO}

\subsection{Da distinção entre meação e herança}

Uma distinção que se impõe esclarecer é a diferença entre meação e herança.

O direito sucessório não se confunde com meação, uma vez que nesta as metades do patrimônio pertencem a cada um dos consortes, enquanto a herança é o patrimônio deixado pelo falecido.

A meação tem origem no direito patrimonial familiar, ou seja, é o patrimônio comum amealhado pelo casal na constância do casamento, dependendo do regime de bens adotado. Nada mais é que "os bens comuns, isto é, pertencentes às duas pessoas que foram casadas devem ser divididos". 27

Assim, não há como confundir herança e meação. São institutos diversos: um situa-se no âmbito do direito sucessório e o outro pertence ao direito das famílias e é condicionado ao regime de bens do casamento. ${ }^{28}$

24 Art. $5^{\circ}$. Todos são iguais perante a lei, sem distinção de qualquer natureza, garantindo-se aos brasileiros e estrangeiros residentes no país a inviolabilidade do direito à vida, à liberdade, à igualdade, à segurança e à propriedade [...].

25 Art. $1^{\circ} \mathrm{A}$ República Federativa do Brasil, formada pela união indissolúvel dos Estados e Municípios e do Distrito Federal, constitui-se em Estado Democrático de Direito e tem como fundamentos [...]; III. a dignidade da pessoa humana.

26 Art. 1.672. No regime de participação final nos aquestos, cada cônjuge possui patrimônio próprio, consoante disposto no artigo seguinte, e lhe cabe, à época da dissolução da sociedade conjugal, direito à metade dos bens adquiridos pelo casal, a título oneroso, na constância do casamento.

27 VENOSA, Sílvio de Salvo. Direito Civil: direito das sucessões. 4. ed. São Paulo: Atlas, 2004, p. 108.

28 DIAS, Maria Berenice. Manual das Sucessões. 3. ed. São Paulo: Editora Revista dos Tribunais, 2013, p. 55. 


\subsection{Da concorrência sucessória}

Sucessão é "a transferência de bens de uma pessoa a outra, que pode ser de duas formas: por vontade das partes ou em razão da morte". ${ }^{29}$

O Código Civil alçou o cônjuge à condição de herdeiro necessário (art. 1845 do Código Civil $^{30}$ ), tendo, este, direito à legítima (art. 1846 do Código Civil $^{31}$ ), e, em regra, não podendo ser afastado da herança por disposição de última vontade, a não ser que incida na espécie as hipóteses de renúncia, indignidade ou deserdação.

$\mathrm{O}$ cônjuge foi alçado à categoria de herdeiro necessário e concorrerá (obedecidos alguns requisitos) com os descendentes e (sem nenhum requisito) com os ascendentes, logo nas primeiras convocações sucessórias. ${ }^{32}$

Ao tratar sobre o tema, o professor Guilherme Calmon Nogueira da Gama afirma:
O art. 1829 do novo Código Civil apresenta a grande novidade na matéria porque insere o cônjuge ao lado dos parentes na linha reta descendente e na linha reta ascendente, demonstrando o prestígio que a pessoa do cônjuge recebe com a nova ordem jurídico-privatística instaurada com o Código Civil de $2002 .{ }^{33}$

Sabe-se que a qualidade de herdeiro necessário é de grande valia, pois a ele é conferido o benefício da legítima, a qual consiste na porção de bens que o testador não pode testar nem doar por pertencer, de pleno direito, aos herdeiros necessários. ${ }^{34}$

A razão primeira de tal mudança - cônjuge como herdeiro necessário - remonta à alteração radical no tocante ao regime de bens, antes prevalecendo o da comunhão universal, de tal maneira que cada cônjuge era meeiro, não havendo razão alguma

29 DIAS, Maria Berenice. Manual das Sucessões. 3. ed. São Paulo: Editora Revista dos Tribunais, 2013, p. 99.

30 Art. 1.845. São herdeiros necessários os descendentes, os ascendentes e o cônjuge. 31 Art. 1.846. Pertence aos herdeiros necessários, de pleno direito, a metade dos bens da herança, constituindo a legítima.

32 NICOLAU. Gustavo Rene. Sucessão legítima no Novo Código Civil. Revista IOB de Direito de Família. V. 9, n. 44. Porto Alegre: Editora síntese, 2007, p. 50.

33 GAMA. Guilherme Calmon Nogueira da. Concorrência Sucessória à luz dos Princípios norteadores do Código Civil. Revista Brasileira de Direito de Família. V. 7, n. 29. Porto Alegre: Editora Síntese, 2005, p. 22.

34 DINIZ, Maria Helena. Sucessão do cônjuge, da companheira e outras histórias (Coord.). São Paulo: Editora Saraiva, 2013, p. 11. 
para ser herdeiro. Tendo já a metade do patrimônio, ficava excluída a ideia de herança. ${ }^{35}$

Não há dúvida de que o direito concorrencial integra o acervo hereditário, pois herança é.

$\mathrm{Na}$ ordem de vocação hereditária (art. 1829 do Código Civilis6), o cônjuge sobrevivente aparece no terceiro lugar, após os descendentes e ascendentes. Inclusive, à inteligência do art. 1838 Código $\mathrm{Civil}^{37}$, a falta de descendentes e ascendentes será deferida por inteiro o patrimônio do autor da herança independente do regime de bens.

A proteção legislativa ao cônjuge foi tanta que lhe restou reservada uma quarta parte em concorrência com os descendentes (art. 1832 do Código Civil ${ }^{38}$ ).
$\mathrm{Na}$ ordem de vocação hereditária quanto à concorrência sucessória, não resta dúvida que sempre haverá com os ascendentes (art. 1829, inciso II, do Código Civil $\left.{ }^{39}\right)$.

A questão polêmica, de dissenso na doutrina e na jurisprudência, fica reservada ao art. 1829, inciso I, do Código Civil, "in verbis":

Art. 1.829. A sucessão legítima defere-se na ordem seguinte:

I. aos descendentes, em concorrência com o cônjuge sobrevivente, salvo se casado este com o falecido no regime da comunhão universal, ou no da separação obrigatória de bens (art. 1.640, parágrafo único); ou se, no regime da comunhão parcial, o autor da herança não houver deixado bens particulares; [...].

35 LEITE. Eduardo de Oliveira. Comentário ao Novo Código Civil. V. XXI. 4. ed. Rio de Janeiro: Forense, 2005, p. 216.

36 Art. 1.829. A sucessão legítima defere-se na ordem seguinte: I. aos descendentes, em concorrência com o cônjuge sobrevivente, salvo se casado este com o falecido no regime da comunhão universal, ou no da separação obrigatória de bens (art. 1.640, parágrafo único); ou se, no regime da comunhão parcial, o autor da herança não houver deixado bens particulares; II. aos ascendentes, em concorrência com o cônjuge; III. ao cônjuge sobrevivente; IV. aos colaterais.

37 Art. 1.838. Em falta de descendentes e ascendentes, será deferida a sucessão por inteiro ao cônjuge sobrevivente.

38 Art. 1.832. Em concorrência com os descendentes (art. 1.829, inciso I) caberá ao cônjuge quinhão igual ao dos que sucederem por cabeça, não podendo a sua quota ser inferior à quarta parte da herança, se for ascendente dos herdeiros com que concorrer.

39 Art. 1.829. A sucessão legítima defere-se na ordem seguinte: [...]; II. aos ascendentes, em concorrência com o cônjuge. 


\subsection{Da concorrencia no regime de bens da comunhão parcial}

A despeito de a norma ser prolixa e de difícil compreensão, cumpre esclarecer, antes de adentrar no tema proposto, que no regime da comunhão universal inexiste falar em direito de concorrência do cônjuge. Já na comunhão parcial de bens, sempre houve divergência na doutrina, porquanto há posicionamentos opostos em relação ao tema.

Uma corrente aponta no sentido de que, se a lei não traz nenhuma restrição, não cabe ao intérprete fazê-lo. Dessa forma, o cônjuge sobrevivente herdaria sobre todo o acervo patrimonial do casal, além de receber metade dos bens comuns pela meação, ele ainda teria direito a herdar, em concorrência com os descendentes quanto aos bens exclusivos do falecido, o que redundaria, como podemos observar, em um tratamento extremamente privilegiado do cônjuge superveniente em relação aos demais herdeiros. ${ }^{40}$

Nesta esteira o escólio de Maria Helena Diniz:

A lei não diz que a herança do cônjuge só recai sobre os bens particulares do de cujus e para atender ao princípio da operabilidade, tornando mais fácil o cálculo para partilha da parte cabível a cada herdeiro. A existência de tais bens é mera condição ou requisito legal para que o viúvo, casado sob o regime de comunhão parcial, tenha capacidade para herdar, concorrendo, como herdeiro, com o descendente, pois a lei convoca à sucessão legítima. Além disso: a) a herança é indivisível, deferindo-se como um todo unitário, ainda que vários sejam herdeiros $(\mathrm{CC}$, art. 1.791 e parágrafo único); o viúvo que for ascendente dos herdeiros (descendentes do de cujus), tem direito a uma quota não inferior a um quarto da herança (CC, art. 1832); c) o cônjuge supérstite é herdeiro necessário (CC, arts. 1.845 e 1.846), tendo direito à quota legitimaria a ser respeitada na sucessão testamentária, visto que o de cujus só poderá dispor de sua porção disponível (metade da herança). ${ }^{41}$

A outra corrente é encampada pelo enunciado 270 da III Jornada de Direito Civil:

Art. 1.829: O art. 1.829, inc. I, só assegura ao cônjuge sobrevivente o direito de concorrência com os descendentes do autor da herança quando casados no regime da separação

40 PALMA, Eduardo Oliva. As novas perspectivas do direito das sucessões em tempos de modernidade e pós-modernidade. (Org. por Carlos Silveira Noronha.) Porto Alegre: Editora Sulina, 2011, p. 128.

41 DINIZ, Maria Helena. Curso de direito civil brasileiro: direito das sucessões. 26. ed.. São Paulo: Editora Saraiva, 2012, p. 147. 
convencional de bens ou, se casados nos regimes da comunhão parcial ou participação final nos aquestos, o falecido possuísse bens particulares, hipóteses em que a concorrência se restringe a tais bens, devendo os bens comuns (meação) serem partilhados exclusivamente entre os descendentes. (grifo nosso)

Como visto, somente aos bens particulares, isto é, aqueles adquiridos anteriormente à celebração do casamento, poderia concorrer o cônjuge sobrevivente, enquanto os bens comuns seriam partilhados entre os herdeiros do morto.

Aliás, esse é o entendimento do Tribunal de Justiça gaúcho:

AGRAVO DE INSTRUMENTO. SUCESSÕES. INVENTÁRIO E PARTILHA. SUCESSÃO DO CÔNJUGE. ART. 1829, I, DO CÓDIGO CIVIL. CASAMENTO SOB O REGIME DA COMUNHÃO PARCIAL DE BENS. MEAÇÃO SOBRE OS AQUESTOS E DIREITOS HEREDITÁRIOS APENAS SOBRE OS BENS PARTICULARES. Quando casados sob o regime da comunhão parcial de bens, em havendo bens particulares, a sucessão do cônjuge defere-se ao sobrevivente em concorrência com os descendentes apenas em relação a estes, uma vez que sobre os bens comuns já lhe tocará a meação. Enunciado n. ${ }^{\circ} 270$ das Jornadas de Direito Civil do CECJF. NEGARAM PROVIMENTO. UNÂNIME. (Agravo de Instrumento $\mathrm{N}^{\circ}$ 70053084083, Oitava Câmara Cível, Tribunal de Justiça do RS, Relator:
Luiz Felipe Brasil Santos, Julgado em: 04/04/2013).

APELAÇÃO CÍVEL. SUCESSÃO DO CÔNJUGE CASADO SOB REGIME DA COMUNHÃO PARCIAL DE BENS. ART. 1829, I, DO CPC. DIREITOS HEREDITÁRIOS SOBRE OS BENS PARTICULARES. $\mathrm{O}$ cônjuge supérstite casado pelo regime da comunhão parcial de bens possui direito sucessório em concorrência com os descendentes, quando o inventariado deixar bens particulares. O cônjuge sobrevivente, nesta hipótese, herda apenas os bens particulares. Apelação desprovida. (Apelação Cível No 70052298031, Sétima Câmara Cível, Tribunal de Justiça do RS, Relator: Jorge Luís Dall'Agnol, Julgado em: 27/03/2013).

AGRAVO DE INSTRUMENTO. SUCESSÃO DO CÔNJUGE. ART. 1829, I, DO CÓDIGO CIVIL. CASAMENTO SOB O REGIME DA COMUNHÃO PARCIAL DE BENS. MEAÇÃO SOBRE OS AQUESTOS E DIREITOS HEREDITÁRIOS APENAS SOBRE OS BENS PARTICULARES. QUANDO CASADOS SOB O REGIME DA COMUNHÃO PARCIAL DE BENS, A SUCESSÃO DO CÔNJUGE DEFERE-SE AO SOBREVIVENTE

EM CONCORRÊNCIA COM OS DESCENDENTES APENAS EM RELAÇÃO AOS BENS PARTICULARES, UMA VEZ QUE SOBRE OS BENS COMUNS, JÁ LHE TOCARÁ A MEAÇÃO. NEGARAM PROVIMENTO. UNÂNIME. (Agravo de Instrumento $\mathrm{N}^{\circ}$ 70045853652, Sétima Câmara Cível, Tribunal de Justiça do RS, Relator: Liselena Schifino Robles Ribeiro, Julgado em: 28/03/2012). 
Casado no regime de comunhão parcial, existindo bens particulares, o cônjuge terá o mesmo quinhão dos descendentes que herdarem por cabeça (art. 1832, CC), ressalvando a lei que, se os descendentes do falecido também forem do cônjuge sobrevivente, este não poderá receber menos de um quarto da herança. ${ }^{42}$

Apesar das divergências, o Superior Tribunal de Justiça pacificou a questio, ao afirmar que "preserva-se o regime da comunhão parcial de bens, de acordo com o postulado da autodeterminação, ao contemplar o cônjuge sobrevivente com o direito à meação, além da concorrência hereditária sobre os bens comuns, mesmo que haja bens particulares, os quais, em qualquer hipótese, são partilhados unicamente entre os descendentes" ${ }^{\prime 4}$.

\subsection{Da concorrência sucessória no regime de separação de bens}

A separação de bens divide-se em duas subespécies: convencional e obrigatória.

A primeira, como o nome diz, utilizando-se da autodeterminação e autonomia da vontade, os cônjuges escolhem livremente que não haverá comunhão patrimonial na vigência do casamento, cada qual administrando seus bens como melhor lhe aprouver.

De outra banda, a separação obrigatória é aquela em que o império da lei impõe de forma cogente aos nubentes a celebração do casamento no respectivo regime, nos moldes do art. $1641^{44}$ do Código Civil.

Cinge-se a indagação quanto à possibilidade do cônjuge ter direito concorrente à herança, quando livremente convenciona o regime de separação de bens. Isto porque o artigo de lei afirma não haver que se falar em herança, "salvo se casado este com o falecido no regime da separação obrigatória de bens" ${ }^{\prime 45}$.

42 CARVALHO. Dimas Messias de. Direito das sucessões. 3. ed. Belo Horizonte: Editora Del Rey, 2011, p. 61.

43 REsp 992749/MS, Rel. Ministra NANCY ANDRIGHI, TERCEIRA TURMA, Julgado em: 01/12/2009, DJe 05/02/2010, REsp 1117563/SP, Rel. Ministra NANCY ANDRIGHI, TERCEIRA TURMA, Julgado em: 17/12/2009, DJe 06/04/2010.

44 Art. 1.641. É obrigatório o regime da separação de bens no casamento: I. das pessoas que o contraírem com inobservância das causas suspensivas da celebração do casamento; II. da pessoa maior de 70 (setenta) anos (Redação dada pela Lei n ${ }^{\circ} 12.344$, de 2010); III. de todos os que dependerem, para casar, de suprimento judicial.

45 Art. 1.829. A sucessão legítima defere-se na ordem seguinte: I. aos descendentes, em concorrência com o cônjuge sobrevivente, salvo se casado este com o falecido no regime da comunhão universal, ou no da separação obrigatória de bens (art. 1.640, parágrafo único); ou se, no regime da comunhão parcial, o autor da herança não houver deixado bens particulares. 
A questão é polêmica, existindo vozes dissonantes, tanto na doutrina, quanto na jurisprudência. Ad exemplum, trazemos a colação julgado recente do Tribunal gaúcho, reconhecendo o direito concorrente no regime de separação convencional de bens, conforme ementado:

INVENTÁRIO. ORDEM DE VOCAÇÃO HEREDITÁRIA. CONCORRÊNCIA DO CÔNJUGE SUPÉRSTITE COM O FILHO. CABIMENTO. 1. A lei que rege a capacidade sucessória é aquela vigente no momento da abertura da sucessão. Inteligência dos art. 1.787 do CCB. 2. Tendo o casamento sido realizado pelo regime da separação convencional de bens, o cônjuge supérstite deve ser chamado para suceder, concorrendo com o filho do casal aos bens deixados pelo falecido. [...] Recurso desprovido. (Agravo de Instrumento No 70054717319, Sétima Câmara Cível, Tribunal de Justiça do RS, Relator: Sérgio Fernando de Vasconcellos Chaves, Julgado em: 21/05/2013)

Ao sentir do ínclito julgador, muito embora as partes fossem casadas no regime de separação convencional de bens, ante a escritura de pacto antenupcial, a cônjuge seria herdeira, por meio de direito concorrencial próprio, uma vez que o dispositivo legal nada fala quanto ao regime $s u b$ judice, havendo somente norma regulamentadora quanto ao regime de separação obrigatória de bens.

No voto, o julgador corrobora sua posição, afirmando que a hermenêutica jurídica veda a interpretação extensiva da exceção.

Por outro lado, Karime Costalunga, em obra que abordou o tema, opõe-se a esta possibilidade, porquanto a comunicabilidade patrimonial pós-morte seria tal qual alteração de regime de bens:

Nessa perspectiva, tendo em vista a estrutura sistemática do Código, o seu caráter dotado de ordem e unidade pressupõe a quebra da coerência axiológica decorrente da circunstância de, concomitantemente, a ser reconhecida aos nubentes a possibilidade de autodeterminação para escolherem a separação patrimonial e a eles ser negada essa mesma possibilidade pela imposição de uma comunicabilidade do mesmo post mortem. Por que poderiam escolher a incomunicabilidade patrimonial se os bens de um vão, coativamente, comunicar-se com os do outro após a morte? Vale dizer que não há harmonia axiológica. ${ }^{46}$

Propõe, ainda, a doutrinadora, a possibilidade de feitura de testamento, se o cônjuge pretender a comunicação dos bens particulares após o decesso. 
Ademais, o Superior Tribunal de Justiça, responsável em uniformizar a interpretação da lei federal, já se manifestou sobre o assunto.

No julgamento do Recurso Especial $\mathrm{n}^{\circ}$ 992.749/MS ${ }^{47}$, de relatoria da Ministra Nancy Andrighi, após longo arrazoado sobre as correntes que interpretam o dispositivo legal, assenta quanto à separação de bens o seguinte:

[...] A separação de bens, que pode ser convencional ou legal, em ambas as hipóteses é obrigatória, porquanto na primeira, os nubentes se obrigam por meio de pacto antenupcial - contrato solene-lavrado por escritura pública, enquanto na segunda, a obrigação é imposta por meio de previsão legal.

Sob essa perspectiva, o regime de separação obrigatória de bens, previsto no art. 1.829, inc. I, do CCO2, é gênero que congrega duas espécies: (i) separação legal; (ii) separação convencional. Uma decorre da lei e, a outra, da vontade das partes, e ambas obrigam os cônjuges, uma vez estipulado o regime de separação de bens, à sua observância.

Dessa forma, não remanesce, para o cônjuge casado mediante separação de bens, direito à meação, salvo previsão diversa no pacto antenupcial, tampouco à concorrência sucessória, respeitando-se o regime de bens estipulado, que obriga as partes na vida e na morte. Nos dois casos, portanto, o cônjuge sobrevivente não é herdeiro necessário. [...].

Entendeu a Relatora que separação é gênero, que mescla duas espécies: separação legal e separação convencional.

Portanto, não faz jus o cônjuge sobrevivente à condição de herdeiro.

A propósito, o Tribunal da cidadania corroborou a proposição em outros julgados: Ag 104754/RS, Rel. Ministro Aldir Passarinho, (decisão monocrática), julgado em: 26/10/2010, DJe 05/11/2010, REsp 1111095/RJ, Rel. Ministro CARLOS FERNANDO MATHIAS (JUIZ FEDERAL CONVOCADO DO TRF $1^{\text {a }}$ REGIÃO), Rel. p/ Acórdão Ministro FERNANDO GONÇALVES, QUARTA TURMA, julgado em: 01/10/2009, DJe 11/02/2010.

Como observado, o Superior Tribunal de Justiça mantém posicionamento da impossibilidade de concorrência sucessória no regime de separação livre de bens.

\section{CONSIDERAÇÕES FINAIS}

A proposta do presente ensaio, que não teve a pretensão de esgotar o tema, 
foi de fazer uma singela ponderação da influência da escolha do regime de bens quando da morte de um dos consortes quanto à participação dos mesmos na herança.

Primeiro, fizemos uma incursão histórica nas origens romanas do regime de bens. Após, passamos pela evolução no direito nacional, com a entrada em vigor do Estatuto da $\mathrm{Mu}-$ lher Casada (Lei 4.121/67) e Lei do Divórcio (Lei 6.515/77), que introduziram de forma incipiente uma nova concepção de sociedade conjugal, não mais aquela patriarcal, na qual havia o vilipêndio dos direitos mínimos da mulher. Com a edição da Constituição cidadã, houve uma real e concreta modificação da visão da mulher perante a sociedade. Não mais a mulher era tratada como "coisa", "sócia" ou, ainda pior, "prestadora de serviços domésticos". Na edição do Código Civil de 2003, como efeito imediato da Carta Magna, a mulher consolidou sua posição perante a sociedade conjugal ao açambarcar direitos de igualdade com o homem.

Dentre esses "novos" direitos, podemos afirmar que o regime de bens sofreu forte influência na patrimonialização da mulher quando do fim do casamento ou do decesso do cônjuge.

Passou-se a adotar, de lege lata, a comunhão parcial de bens como regime legal. Nossa legislação substantiva aduz, ainda, a existência de quatro outros possíveis regimes de bens, são eles: comunhão universal de bens, separação convencional e obrigatória de bens e, por fim, a participação final nos aquestos. Esclarece-se que o legislador apenas noticiou um norte, um caminho, não havendo óbice na escolha de regimes de bens híbridos, desde que não contrariem disposição de lei. Outras duas inovações foram a possibilidade de alteração do regime de bens e, a que nos interessa, a concorrência sucessória do cônjuge com os descendentes quando da abertura da sucessão.

O cônjuge, antes tão excluído, foi guindado a herdeiro necessário na ordem de vocação hereditária, tendo privilégio de concorrer na herança do morto com a classe dos descendentes. Além disso, não poderá sua quota parte ser menor que um quarto da herança.

Contudo, apesar de todas as vantagens atribuídas ao cônjuge, a doutrina e a jurisprudência andaram em mares turbulentos quanto ao instituto da concorrência sucessória, havendo divergências e posicionamentos antagônicos em relação ao tema.

Analisamos, principalmente, dois regimes de bens: a comunhão parcial e a separação de bens, até porque, ao nosso ver, são estes os mais contraditórios doutrinariamente.

No regime de comunhão parcial de bens, existem fundamentalmente duas correntes. De acordo com a primeira, na hipótese de o autor da herança ter deixado bens particulares, o cônjuge 
supérstite herda sobre a totalidade da herança, sejam eles aprestos ou aquestos. Todavia, não havendo bens particulares, não fala-se em herança.

A segunda corrente sustenta que, possuindo o de cujus bens particulares, somente sobre estes haveria concorrência, e os bens comuns seriam partilhados apenas pelos descendentes.

O Superior Tribunal de Justiça, em julgamento paradigmático, criou uma nova exegese para o dispositivo de lei. Afirmou que, no regime da comunhão parcial, tem direito concorrencial tão somente o cônjuge em relação aos bens comuns, independente de haver ou não bens particulares.

Ao nosso sentir, andou bem o Tribunal da cidadania, pois, no regime de comunhão parcial, todos os bens amealhados na constância do casamento subentende-se que houve desforço do casal para adquiri-lo. Portanto, os bens que foram adquiridos pelo esforço comum dos consortes, devem sofrer os efeitos da concorrência sucessória. Por sua vez, os bens particulares, aqueles que os nubentes já tinham antes do enlaço matrimonial, não pertencem ao cônjuge, devendo ser partilhados somente entre os herdeiros, ou seja, seus descendentes, pois não houve esforço comum para sua conquista.

Quanto ao regime de separação de bens, é gênero que congrega duas espécies: convencional e obrigatória.
$\mathrm{Na}$ separação livremente pactuada, a Superior Instância, a despeito de posicionamento diverso do Tribunal $a$ quo, disse que não há necessidade de falar em herança, pois, se assim o fosse, seria alterado o regime após a morte.

Ao nosso juízo, a interpretação exalada pelo Tribunal Estadual, que admite a concorrência, parece estar em maior harmonia com a norma que regula a ordem de vocação hereditária aos descendentes.

Se quisesse o legislador ordinário abranger o regime de separação convencional de bens, teria demonstrado expressamente. Ao contrário, previamente atestou que no regime de separação obrigatória não gozaria o cônjuge do benefício da concorrência.

Ora, como bem afirmou o julgado do Tribunal de Justiça, a exegese não pode ir além do que foi preceituado na norma, que achou por bem aventar apenas a separação obrigatória.

Ademais, tivesse desejado que não fosse o consorte contemplado com parte da herança, teria o legislador apenas dito de forma genérica: " $o$ regime de separação de bens", reconhecendo-se destarte inclusos a separação convencional e obrigatória. Se não o fez, certamente não quis abarcar as duas espécies.

Talvez, uma solução jurídica, seria emendar ou eliminar o adjetivo "obrigatória". Com essa supressão o cônjuge sobrevivente não teria a qualidade de herdeiro "se caso com 
o falecido no regime de comunhão universal ou no de separação de bens". ${ }^{48}$ Desta forma, ao nosso sentir, não há como se alinhar ao decidido pelo Tribunal da cidadania.

Por outro lado, na separação obrigatória de bens, ou seja, regime pelo qual o legislador compulsoriamente impõe que os nubentes se casem sob a égide deste regime, o Superior Tribunal de Justiça afirma que na separação de bens, seja ela legal ou convencional, não resta qualquer direito à meação ou concorrência sucessória.

A fim de não deixar passar in albis, a existência da Súmula 377 do Supremo Tribunal Federal é amplamente aceita pelos nossos Tribunais.

A imposição obrigatória do regime de bens pareceu-nos a melhor interpretação, uma vez que o legislador afirmou, como já aduzido alhures, que nesse o cônjuge não teria direito concorrencial.

Não se olvidando do fato de ser o tema um tanto espinhoso, tentamos fazer uma reflexão teleológica, contribuindo com o debate. Portanto, esta foi uma singela análise de questões divergentes na doutrina e em nossos Tribunais.

\section{REFERÊNCIAS}

BRASIL. STJ. Disponível em: < www. stj.jus.br>.

BRASIL. TJRS. Disponível em $<$ www.tjrs.jus.br>.

BRASIL. Constituição, 1988.

BRASIL. Lei $n^{\circ} 4.121$, de 27 de agosto de 1962.

BRASIL. Lei $\mathrm{n}^{\circ} 6.515$, de 26 de dezembro de 1977.

BRASIL. Lei $\mathrm{n}^{\mathrm{o}} 10.406$, de 10 de janeiro de 2002.

ALVES, José Carlos Moreira. Direito Romano. V. II. 6. ed. Rio de Janeiro: Editora Forense, 2001.
CARVALHO. João Andrades. Regime de bens. Rio de Janeiro: Editora Aide, 1996.

CARVALHO. Dimas Messias de. Direito das sucessões. 3. ed. Belo Horizonte: Editora Del Rey, 2011. COSTALUNGA. Karime. Direito de Herança e Separação de Bens. São Paulo: Quartier Latin, 2009.

DIAS, Maria Berenice. Manual das Sucessões. 3 ed. São Paulo: Editora Revista dos Tribunais, 2013. - Manual de Direito das Famílias. 9. ed. São Paulo: Editora Revista dos Tribunais, 2013.

48 REALE, Miguel. Estudos Preliminares do Código Civil. São Paulo: Editora Revista dos Tribunais, 2004, p. 63. 
DINIZ, Maria Helena. Sucessão do cônjuge, da companheira e outras histórias. (Coord.) São Paulo: Editora Saraiva, 2013. Curso de direito civil brasileiro: direito das sucessões. 26. ed. São Paulo: Editora Saraiva, 2012 GAMA. Guilherme Calmon Nogueira da. Concorrência Sucessória à luz dos princípios norteadores do Código Civil. Revista Brasileira de Direito de Família. V. 7, n. 29. Porto Alegre: Editora Síntese, 2005.

GONÇALVES. Carlos Roberto. Direito Civil brasileiro. V. 6. Direito de família. 8. ed. São Paulo: Editora Saraiva, 2011.

IHERING, Rudolph Von. El espiritu del Derecho Romano em las diversas fases de su desarrolho. Tomo I. Granada: Editora Comares, 2011.

LEITE. Eduardo de Oliveira. Comentário ao Novo Código Civil. V. XXI. 4. ed. Rio de Janeiro: Forense, 2005.
LÔBO, Paulo. Direito Civil. Famílias. 2. ed. São Paulo: Editora Saraiva, 2009.

NICOLAU. Gustavo Rene. Sucessão legítima no Novo Código Civil. Revista IOB de Direito de Família. V. 9, n. 44. Porto Alegre: Editora Síntese, 2007.

PALMA, Eduardo Oliva. As novas perspectivas do direito das sucessões em tempos de modernidade e pós-modernidade. (Org. por Carlos Silveira Noronha.) Porto Alegre: Editora Sulina, 2011.

PEREIRA, Caio Mário da Silva. Instituições ao direito civil. Direito de Família. V. V. 18. ed. Rio de Janeiro: Editora Forense, 2010.

REALE, Miguel. Estudos Preliminares do Código Civil. São Paulo: Editora Revista dos Tribunais, 2004.

VENOSA, Sílvio de Salvo. Direito Civil: direito das sucessões. 4. ed. São Paulo: Atlas, 2004. 